\title{
Concept and Leadership Style in the Story of Munanese Folklore: A Study to the Fairy Tale of Kolope Bhala Tumbu (Gadung/Dioscorea Hispida Dennst)
}

\author{
La Ode Ali Basri ${ }^{1}$, Abdul Halim Momo ${ }^{2}$, Akhmad Marhadi ${ }^{3}$, Abdul Rahman ${ }^{3} \&$ Aswati $^{1}$ \\ ${ }^{1}$ Department of Historical Science, Faculty of Cultural Science of, Universitas Halu Oleo Kendari \\ ${ }^{2}$ Department of Civil Education, Faculty of Teacher Training and education of universitaas Halu Oleo Kendari \\ ${ }^{3}$ Department of Antropology, Faculty of Cultural science of Universitas Halu oleo Kendari \\ Correspondent: La Ode Ali Basri, Department of Historical Science Faculty of Cultural Science of Universitas \\ Halu Oleo Kendari, Southeast Sulawesi, Indonesia. Tel: 081-341-797-344. E-mail: basri.uho74@gmail.com
}

Received: July 30, 2017

Accepted: August 24, 2016

Online Published: August 31, 2017

doi:10.5539/ach.v9n2p83

URL: http://dx.doi.org/10.5539/ach.v9n2p83

\begin{abstract}
The purpose of the study was to describe and analyze the concept and model of the style of leadership in muna communities which was abstracted through the story of Kolope Bhala Tumbu (cassava or gadung/dioscorea hispida dennst). Data was collected by depth interview, documentation, and focused discussion. Data was analyzed by data reduction, data displaying and conclusion. Result of the study showed that the concept of leadership contains in the story of Kolope Bhala Tumbu as follows; 1) leading by ear, means that a leader is a listener, 2) leading by action indicates that a leader is a controler, server, and colaborator, 3) leading by charming that is a leader is a character that is respected not to be feared. as the criterion he must have a good heart, good deeds, open minded, be intelectual, clean, respecting, caring and loving, and always down to earth. A leader must see that his authority of leading is limited by ethics and moral that allowed him to rule. The style of leadership in the story of kolope bhala tumbu was a democratic-humanist style. This could be seen from the period of sucetion that run failry, transparancy, open, and volunterily through the proces of deliberation. In the end of the sucetion, paddy was augurated as the leader for the plants as he was considered to have all the good characters and criterion, able and capable. This story decsribed that the power of leading is limited by ethics and morals. This story could be inspiring the humans in the modern era to be a respected leader.
\end{abstract}

Keywords: oral tradition, reinterpretation of a folk story, concept and style of leadership

\section{Introduction}

Folk strory is a literary work which comprised of local literature like myhts or legend expressed the aspects of social and culture and other aspects. According to Sediawati (2014) and Basri et al. (2017) stated that folk story which recounted the system of the inherritance of values, history, the characteristic of life from time to time of the generations in times to come. In the past time, folk story was recounted orally and inherited to next generation in oral, otherwise, today folk stories could be found out in the form of book story, comic, animation and other (Basri, 2017).

Meanwhile, Nurlela and Harijanty (2011) stated that folk story contains a lesson and moral as well education meanings, while Basri, (2017) said it is a local wisdom where it did not only recording the activity of its community, but also its exprssing the philosophy, model and style of leadership of a community. Folk story could be a media to give critics and suggesions to social phenomenon as done by Boal (1998) who gave a critical opinion and teased the Mayor of Rio de Jeneiro as untrusted leader. Toin the story of Brazilians entitled Evil and an inteligent man, told that even evil promised to benefit himself, would still keep his promise to a poor inteligent farmer by leting him benefiting his harvesting. Therefore, the leader of human beings should be more moralist and be more ethique in his governance.

The study of a leadership by adopting the values of local societies was also conducted by Kennedy (2002) in Malaysia. Result of the study showed that leadership behaviour in Malaysia was strongly influenced by traditional values, one of the values of the tradition that influenced this leadership behaviour was the culture of respecting and 
avoiding the action of confronting. A Consistent leadership style corelating to the values of social is effectively considered and could be accepted to a leadership style by using an approach of conflict. Meanwhile, Smith (2003) in his study of a leadership in Sahara-Africa stated that a life consideration and traditional culture of the Africans gave a great contribution for the leadership there. In their consideration, among others was stated that group's interest should come before indivdual interest, as well a leader must put his group's importance to his individual willing. In accordance with the resut of the research of Satori and Agung (2017) concerning to a traditional leadership in the plurality of the community within Ciamis of West Java, said that a leader must be able to create a peace condition in a social life. To bring such condition, a charimatic leader is required who can shleter all of the groups. Therefore, Corcoran and Jr.Welman (2016) stated that a charismatic leadership are relatable, authentic, and trustable. Within the perspective of Woods (2004) the style of leadership which is charismatic and protected all the groups of community are the reflection of a democratic leaderrship.

According to Suryadi (2016) a leader must guard all of his peopel as he is the most powerfull. They belonged to all the rights that others did not own. That is why, a leader is pursuit to protect his people, showed his identity as his characteristic for his peope and showed a good moral and capable. This point of view is in accordance to the findings of Low and Ang (2016) that a fine leader is from the humans or animals that are characterized to lead, to affect, to be an example, guiding, and develop a good cmmunication to with his people. Furthermore, Low and Ang (2016) stated that in his governance, a leader must bring his head, heart and hands. Leading with the rain indicating that a leader must be able to have a good analysis, a good social skills, and impersonal leading by showing. Leading with a heart and willing.

The concepts of leadership which was explained above was the concepts of leadership taken from the knowledge of local community which was sistematically set up in the system of social and traditional culture which were expressed in their life's reflection, folk stories like myth, legend, fairy tale and others. Based on the above findings, the meaning of Muna folk of Kolope Bhla Tumbu is beleved to recount a concep and the style of leadership within the community of Muna in South East Sulawesi of Indonesia, so, this story is expected to be delivered widely and be analyzed scietifically

\section{Research Method}

The study was conducted in the district of Watopute, the Regency of Muna, Southeast Sulawesi. Informants of the study comprised of 1 maestro, 3 elder persons of the Village, 2 persons of member of the community, 2 youths' representative, and 2 others member of community. The informants were purposively detemined. Data was colleceted through : 1) direct observation, that was observers were actively participated in the observation with the informants and directly observed the plant of kolope bhala tumbu which became the object of the story, (2) having a deep interview with the communities either the figure of religion, figure of the culture, the youths, particularly to those who preserved the tradition and other member of societies concerning to ideas, experiences, knowledges, and other related informations of the story of kolope bhala tumbu, (3) conducting a library studies which related to the stories of Muna and other stories, (4) documenting or picturing to physical shape of the plant of kolope bhala tumbu.

Data were analyzed by descriptie-qualiativelly by employing the model of Milles and Huberman (1991) by the following steps; (a) data reduction, in which all data obtained from interviews, observation, study of literature, and focused group discussion were organized, divided one by one, and grouped based on types. Then,the data were reduced in order to eliminate least relevant data. This was followed by making an abstaction and organizing data into several units; (b) data display, in which data were presented through a process of categorization and grouping according to units of analysis with the aim of improving the data. Next,some relationships between categories wereestablished, each category of datawas compared to other categories, and the meanings of each data relationship were interpreted; (c) drawing of conclusions, which was based on the results of data interpretationand supported by valid and consistent evidences.

To conduct the study as planned, several medium and research techniques were employed, including data cards, interview guidelines, and photo camera or video camera to record observation and interviews.

\section{Results and Discussion}

\subsection{Cerita Rakyat Kolope Bhala Tumbu}

Naando sewakutuu sabhara hulano ghoti nefumaando manusia miinamo bhe kaseise. Tangkanomo ntighomo kaawu dopogira-gira. Nepohala-halatighondo ini, lahae so mantasino so nesangke, so membalino neangkado bhari-bharie ghoti nefumaa. Maanano, so membalino kolakino ghoti, so nefongkora te fotu ane dakofaraluu atawa dakokasukara manusia. 
Ee, nefie-fieghoo dopo owi-owilimo bhari-bharindo o ghoti nefumaa. Dopo owi-owilighomo daefonando rompuha, nomudahgoo daepili lahae so membalino kolakino ghoti. Norato kaawu wakutuuno rompuha, dowolomo doghonu hari-bharie nefumaa : o kahitela, o mafu sau, o lamedawa o tonea, o ghofa, o pae, o kolope, o wute, tangkanomo bhari-bharie ghoti nefumaa. Maka welo kabharindo maitu, o kolope ntigho molai-laino wutono. Nobhala mpuu lalonoa dasumangkee naembali kolakino ghoti. Sembali o pae mina bhe bhe diu. Nengkora we tompano ghebhe anoa.

Dowolo kaawu doghonu, minamo bhe so neantagi, aitu nopogaumo kantawu bhari lahae so mantasino soneangkado ghoti nefumaini koana ntigho dopohala-halati. Nopogaumo kolope : 'Ingka pe naohali namisiku daeghondohi. Ane inodi tadaghumondomo. Laha-lahae kaawu so so mewarehino roo, sobhalahino ihi, so kokiri-kirino, so kodhangku-dhangkuno, aituemo so nesangke. Maanano, aitua natibharaki, natimotehi.' Maka o kolope ini anoa newarehi roonoa. Laanoa nokokiri-kiri, nokodhangku-dhangku, ihino welo wite pakade bhe kabhalahi.

Dobhalomo dua sigaahano : 'Aitu mina amandehaane bhaindo, maka ane inodimo semie, suano o mbhadha, suano o fewutoi so neghondono. Naokesa kaawu mbadhano, parewano, natumaratumpu maka fewutoino, ane pe naokesa podiuno, pe naokesa feilino, sapasina aitu, ane pe naewanta fekirino, nakumalolu-lolu, tao kakapudhiamo kaawu so neghodhino, inga pe nakoghuluha dasumangkee so neangkado ghoti. Dadihanomo so nesangke aitu, tabeano so metaano feili, sometaano podiu, so mewantano fekiri. Pe naembalia nakumaampa-ampa, nakumadhoro-dhoro, pe naembalia naelangke lalonoa. Naoasi bhe bhaino, nakokatulumi. Medano anagha beano ane inodi, so nesangke so neangkantoomu bhari-bharie kaetaamu inia.'

Notamba dua sigaahano: 'Inodimo semie, aasianemo nagha peda nepogaughoo aitu. Maanano, suano o ghulua, ofewutoia so neghondo. Tabea o podiu, ofeili, lalo metaa, lalo moasi. Dadihanomo, ane inodi, dasumangkemo o pae maitu so neangkantoomu oghoti nefumaa ini. Uumbemo, ane daghumondo fewutoino, o pae inia nonale laanoa. Maka, ane fekirino, feilino, nofaraluu damangkafie. Nihompu nohende kabharino ihino anoa, nihompu notubhari noungko ne bhaino. Sapasino aitu, ingka taintaidimu dua itu lahae so mantasino.'

Aitu maka o kolope nofetingke anagha nodea hulano, kansuru nobisara: 'Nopeda hae? Dasumangke pae? O hae so nealaghoo ne pae? Laano bhe kanale, damindahie naolepe. Pakade bhe karubuhino bhake. Ghonunoa tapedahimo bhone. Medano inodi beano. O laa sakiri-kiri, o roo kaware, o ihi kabhalahi, pakade dhangku. O hae so nebansi ne idi inia?'

Dofetingke pogauno kolope ini rumatono welo rompuha, kansuru dopokamu-kamunti. Dopokamu-kamuntighomo o kolope ini ntigho nofolai-lai wutono so membalino ompuno ghoti. Norato nohotu pogau nondawu ne pae so neangkando ghoti nefumaa. Aitu maka kakiidono lalonoa kolope mina damili anoa, kansuru nopogau, bhe nobhatatalahao so momaano anoa naewine naefua: 'Aitu ingka garaa mina omasikanaumua ihintuumua. Dadihanomo natumadamo gholeo itu idia agumaatimo wutoku. Akumalamo agumampi welo karuku amekakodokodoho. Tanamombamo nanumaando o manusia namaraluu naomaakanau, aitu naorepu, naosoka. Waesembali naowulekanau deki. Maanano nasumeli kanau, nahumirikanau maka nakumebhakanau. Mada aitu naghumoleokanau, maka namungkame kanau welo laa sumolono nafatogholeo fatoalo. Waesembali narumabukanau nameda anagha maka naembali daomaakanau'.

Pada kaawu nopogau peda nagha noeremo maka nokala. Bhe namelaida mina mengkora-ngkorano. Dadihanomo notandamo wakutu aitu, o kolopea miinamo naelatea atawa natumumbua welo galu, ne mahondo manusia. Sadhiamo anoa kadadihanoa welo karuku. Sapasino aitu ane dofumaaea doparatongka-tongka, domateane pedamo nepulughoono kabhatatalahao. Waesembali dowuleane, doungkamee, maka nembali dofumaaea. Pedamo anagha-nagha tula-tulano Kolope Bhala Tumbu. Dadihanomo ampa aini laha-lahae ntigho mefodhefodhedhenoa atawa molai-laino wutonoa, sadhiamo dokonae 'Kolope Bhala Tumbu'

\subsection{Translation}

Once upon a time, there was a fight among the foods. the fought was caused by the strugle of the power among the plants. After a long conflict, the plants agreed to end up the war and make a peace as well to engage a deliberation o elect a leader for them. A the day of the deliberation all foods like maize, cassava, sweet potatoes, taro and other kinds of food, were all gathered in a yard. However, before the deliberation started, there was a plant promoting himself to be elected for all of the plants that become the source of human's food. This plant is called kolope Bhala Tumbu (gadung). However, other plants did not concern to him.

The deliberation started by giving an opportunity to all the plants to raise their candidates. First of all, cassava wanted to speak out as the first, and he had the chance to say his voice. He directly pointed himself to be elected as the leader and said that other plants were not eligible, by proposing the criterion for being the leaders must 
have a wide leaves, a prickly stem, must have a big seed and fruit, and must have a long beard. therefore, he would be strictly respected by other plants. Yet, his ideas was flatly resonded by other member of the plants, said that physically or body measure are not an ideal criteria for being a leader. No matter how good the phisyc is leader is accepted by his kind heart, he must be open minded, and be humbel to one to another, far from ambition, respecting, loving, caring and have a good relation to other.

All the member of the deliberation agreed. Finally, they seearched for a plant which fullfill all of the criterion mentioned. Paddy was eventually elected, as he was considered a plant with a good heart, down to earh, concern to all of the ideas of the deliberation, by that, cassava was so mad, and mocked to paddy that he had nothing to proud for, he had only a msall stem and easy to break, he had only little fruit like a sand, looked at me, i had all, prickly stem, big fruit, long beard, and wide leaves. looking at this, all the plants were not happy and glanced to each other, feeling no respect from his friends, and once condemed the humans who would eat kolope bhala tumbu would die except they proces and give a good treatment to him, like peeling, cutting, drying, and soaking it into a natural water for 4 days and noights. If human would not do that, once they eat it, they would be poisoned and died. Cassava was also said that sarting from that day he would live alone, and separated from other plants, would grow as a savage plant in the woods and in the farms of human.

The above story recounted a sucesion of a leadership among the plants thrugh a deliberation. Yet, before the sucesion, conflict existed (a long quararel). According to Basri (2017) this situation is a reflection of what hapened to humans' life both in past and future times. Tomas Hobes (Sabine, 1992) stated that in the past time fighting and battling well existed in the middle of humans' life. This condition was called bellum omnium contra omnes (all against all). Those who had a strong power and physisc would dominate other humans or other group of humans. Humans would eat to one to another or this is called by homo homini lupus. According to Nur (2015) as explained in La Galigo that Bugis ethnic before the period of To Manurung as a uniting person, had experienced this similar social conflict which called siandre bale' taue' (attacking to oane others like a fish).

The unstable of political situation eventually brought a collective awareness to make a contract of politic for a capable leader and to protect them from a riots and create a peace and properous community. This phenomen could be also found in the story of Kolope Bhala Tumbu, after a long pogera-gera (conflict) finally, plants lived in peace and agreed to make a contract of politic to create a peace, transparent and fair election through rompuha (deliberation). The deliberation was conducted democratically and humanist, plants freely and openly voicing their odeas and expresions about a character that would be their candidate of the leader (kolaki). Kolope bhala tumbu for example, said that he was a very proper candidate to be a leader. To his opinion, a leader must have a wide leaves, spread to another plant, must have a prickly stem, must have a long beard, and must have a good physic. With those criterion, other plants would obey him. The following is the figure of kolope bhala tumbu (cassava/gadung).
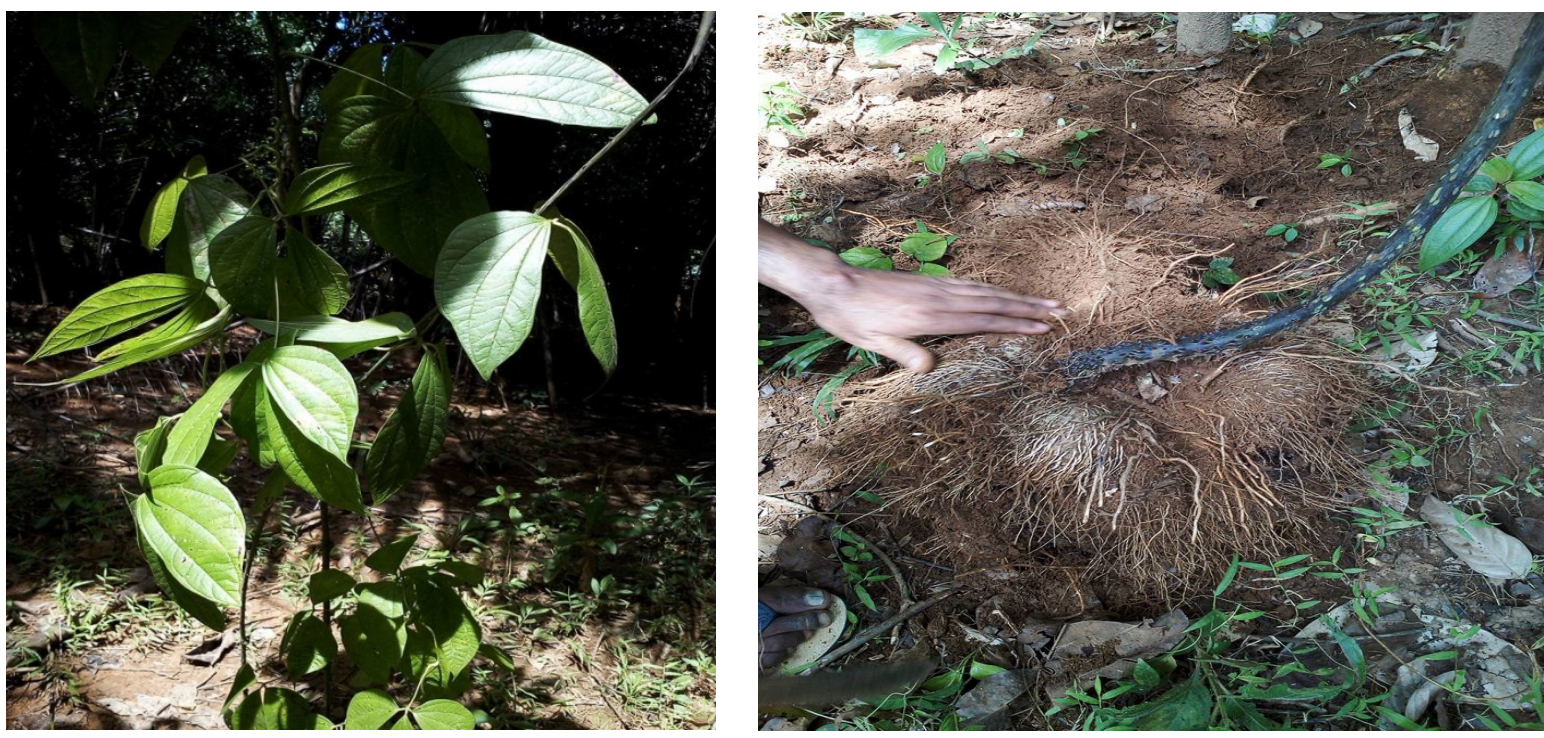

Figure 1 and 2 are the figure of kolope bhala tumbu (cassava or gadung/dioscorea hispida dennst) 
Based on the figure above, it shows that kolope bhala tumbu is a plant with the characteristic he had mentioned, having a wide leaves, spreading, having a prickly stem, etc. These atributes became a symbol of kolope bhala tumbu as they could not be found to other type of plants. Because of these superiorities, he was proud to proclaim himself to lead the plants, yet, he was rejected by other plants. This rejection came out due to physic was not the only criterion to appear as a leader. A good leader should have a good heart, a good deeds, and is able to develop a communication and relationship among others, humble, and must have a good intellectual and the most important ones is respecting others. Besides those criterion, the plants agreed that paddy as the one candidate of the leader. In their opinin, paddy had a good personality and down to earth.

In Muna ethnic, the story of kolope bhala tumbu is a conotative reflection that reflected the concept and the style of a leadership. These concept among others are symbolyzed in the plant of kolope bhala tumbu, with the characteristic he had mentioned. In the perseption of Munanese, a leader must have a wide leaves that indicated that a leader must have a good ear to listen to the probles of his people, hence, a leader must be able to spread indicated that a leader is a controler, this symbolyzed in the habit of kolope bhala tumbu to be able to spread to all the plants both small and big plants. This habit is preumde that kolope bhala tumbu tried to be a good leader, a good controler and to get along with naother plant. Following Reynolds thought et al. (2017), the habit of this plant is identically to the typical of a collaborative leader that must be able to control, gudiding, colaborating and geting along to his people. In the perception of muna ethnic, a leader is also a productive ones like kolope bhala tumbu who was able to produce a big seed and fruit. Besides, a leader must be strict with a charm performance and having the superiorities like what kolope bhala tumbu had, long beard, prickly stem, etc.

Contextualitation of conotative meaning in the story of kolope bhala tumbu as described above, strengthening the opinion of Ampera et al. (2006) that a folk story is a part of oral tradition, where his functon is not only as an entertainment, but also as a media of information from number of subjectively colective opinions and impressions on an urgent, and tyical information of a work. Folk story is not functioned as a strory book which could be consume for a leisure time, however, it is as a reflection of an attitude, information, and as the media of transformation of education (Basri et al., 2017). Folk story also could be a tool for an institution, to preserve the norms in the society (Nurana, 1991).

The sucetion of a leader as described in the story of Kolope bhala tumbu gave a moral message to all humans to be wiser in making a decision through a deliberation not by a certain descision. The plants thought that the election of kolaki (leader) by rompuha (deliberation) was considered more democratic as it could prevent a conflict among them, and the most important ones was the familial relationship is stable. The final steps of this election was paddy eventually elected as the leader for the plants.

Volunteraly, plants trusted paddy to lead them, therefore harmony and the spirit of equality among the plants could be kept after the election. In the contrary of the election for humans, conflict, riot, and other kinds of danger exist, therefore the difference and segmentation of politic appeared. In the theory of perspective, a sucerion of politic in the story of Kolope Bhala Tumbu supported the thesis of Kuntowijoyo (2002) that politic comes within awareness, not by uncivilized presure. Following the the thought of (Barker, 2006) the sucetion of leadership in the story of Kolope Bhala Tumbu run without any group of hegemony both cultural and ideology. So, there was no side dominating their authority of social and showed a power of subordinating. In other terms of leadesrhip sucetion, the story of Kolope Bhala Tumbu reflected a style of leadership humanist and democratic. (Turi, 2007).

The story of Kolope Bhala Tumbu was also recounted that paddy was honoured as kolakino ghoti (leader of food/plants) as he was considered hving a good character and performance of all. Plants had an opinion that a leader must be strict and feared. To be a strict leader, he must have a good character and deeds, would be able to coorporate, humble, not arrogant, loving, caring, and respecting one to another. Besides, a leader must be open minded and humble. These criterion of paddy in the story of Kolope Bhala Tumbu strengtheing that a good leader is a strict ones (Prihandono, 2003). According to Wita (2006) a strict leader had a personality like having the simplicity, similarities, humble to others, avoiding to plagiating one's attitude, dare to take the failure. Wahjono (2005) stated that a leader must be fair, calm, gentle, strict, a source of life for others, responding, open minded, and brave.

\section{Conclusion}

The concept of leadership in the story of Kolope bhala tumbu were as follow: 1) leading by ear, means that a leader is a listener, 2) leading by action indicates that a leader is a controler, server, and colaborator, 3) leading by charming that is a leader is a character that is respected not to be feared. As the criterion he must have a good 
heart, good deeds, open minded, be intelectual, clean, respecting, caring and loving, and always down to earth. A leader must see that his authority of leading is limited by ethics and moral that allowed him to rule.

The style of leadership in the story of kolope bhala tumbu was a democratic-humanist style. This could be seen from the period of sucetion that run failry, transparancy, open, and volunterily through the proces of deliberation. In the end of the sucetion, paddy was augurated as the leader for the plants as he was considered to have all the good characters and criterion, able and capable. This story decsribed that the power of leading is limited by ethics and morals. This story could be inspiring the humans in the modern era to be a respected leader.

\section{References}

Ampera, T., Muhtadin, T., \& Hudayat, A. Y. (2006). Kepemimpinan leluhur Sumedang dalam tradisi lisan: deskripsi dan interpretasi: laporan penelitian. Lembaga Penelitian, Universitas Padjadjaran: Fakultas Sastra, Universitas Padjadjaran.

Barker, C. (2006). Cultural Studies, Teori dan Praktek. Yogyakarta: Kreasi Wacana.

Basri, A., \& Ode, L. (2017). Filosofi Kepemimpinan dalam Cerita Rakyat Kolope Bhala Tumbu pada Masyarakat Muna. Dalam: Prosiding Seminar Pengembangan Pengetahuan Sastra dan Budaya Sebagai Upaya Meningkatkan Pengetahuan dan Apresiasi Terhadap Keragaman Budaya Bangsa. Denpasar 26-27 Mei 2017. Hal.363-370.

Basri, A., Ode, L., Aso, L., Momo, H., Mudana, A., Wayan, I., Taena, L., Salniwati, Janu, L., \& Aswati. (2017). The Valuas of Multicultural Education in Munanese Traditional Culture. Asian Culture and History, 9(1), 33-39.

Boal, A. (1998). Legislative Theatre Using Performance To Make Politics. London: Routledge.

Corcoran, K. E., \& Wellman, J. K. (2016). "People Forget He's Human": Charismatic Leadership in Institutionalized Religion. Sociology of Religion, 77(4), 309-333.

Hutomo, S. S. (1991). Cerita Kentrung: Seni Pertunjukan di Jawa Timur. Jakarta: Pusat Pembinaan dan Pengembangan Bahasa.

Kennedy, C. J. (2002). Leadership in Malaysia: Traditional Values, International Outlook. Academy of Management Executive, 16(3), 15-26.

Kuntowijoyo. (2002). Selamat Tinggal Mitos Selamat Datang Realitas: Esei-esei Budaya dan Politik. Bandung: Mizan.

Low, K. C. P., \& Ang, S. L. (2010, January). Leadership Lessons from the Animal Kingdom?. In e-Leader Conference, Chinese American Scholars' Association: CASA (pp. 4-6).

Milles, M. B., \& Huberman, M. A. (1991). Analisis data Kualitatif. Jakarta: UI Press.

Nur, R. (2015). Mencandra Pemimpin Indonesia dalam Budaya Lokal. Makalah disajikan dalam Seminar Nasional Sejarah dan Budaya, Kamis, 23 Juli 2015, Kampus UHO.

Nurana. (1991). Tatakrama di Lingkungan Keluarga dalam Cerita Rakyat. Jakarta: Depdikbud

Nurlaela, \& Harijaty. (2011). Kajian Moralitas dalam Cerita Rakyat Buton: Lakina Jaya, Bungaeda, dan Laontolu. Jurnal Humanika, 3(2), 1-11.

Prihandono, D. (2003). On Becoming Effective Leader. Jakarta: Elex Media Komputindo.

Reynolds, S., Tonks, A., \& MacNeill, K. (2017). Collaborative Leadership in the Arts as a Unique Form of Dual Leadership. The Journal of Arts Management, Law, and Society, 47(2), 89-104.

Sabine, G., H. (1992). Teori-Teori Politik. Bandung: Binacipta.

Satori, A., \& Agung, S. (2017). Traditional Leadership Model of Pluralistic Society in Ciamis District. International Journal of Multicultural and Multireligious Understanding, 4(1), 15-24.

Sediawati, E. (2014). Kebudayaan di Nusantara. Depok: Komunitas Bambu.

Smith, B. (2003). Worldview and Culture: Leadership in Sub- Sahara Africa. New England Journal of Public Policy, 19(1), 9-21.

Suryadi, K. (2016). Kepemimpinan Mubah. Harian Pikiran Rakyat, 25 Maret 2016.

Turi, O, L. (2007). Esensi Kepemimpinan Bhinci-Bhinci Kuli Suatu Tinjauan Kepemimpinan Lokal Nusantara. Bau-Bau: Khazanah Nusantara. 
Wahjono, P. (2005). Ungkapan-ungkapan dalam Ajaran Jawa: Kearifan dalam Berdemokrasi. Dalam: Demokrasi dalam Budaya Lokal. Penyunting: Mulyana. Yogyakarta: Tiara Wacana.

Wita, W. I. (2006). Pemimpin dan Memimpin Bali. Makalah disajikan dalam Seminar Model Kepemimpinan Bali, Rabu, 13 September 2006, Kampus Unud.

Woods, A. P. (2004). Democratic Leadership: Drawing Distictions with Distributed Leadership. International Journal of Leadership in Education, 7(1), 3-26.

\section{Copyrights}

Copyright for this article is retained by the author(s), with first publication rights granted to the journal.

This is an open-access article distributed under the terms and conditions of the Creative Commons Attribution license (http://creativecommons.org/licenses/by/3.0/). 